\title{
A New Bioactive Steroidal Saponin from Leaves of Furcraea gigantea
}

\author{
Bernadete P. da Silva and José P. Parente \\ Laboratório de Química de Plantas Medicinais, Núcleo de Pesquisas de Produtos Naturais, \\ Universidade Federal do Rio de Janeiro, PO Box 68045 CEP $21944-970$ Rio de Janeiro, Brazil \\ Reprint requests to Prof. Dr. J. P. Parente. Fax: +55-21-2562-6791. E-mail: parente@nppn.ufrj.br \\ Z. Naturforsch. 61b, 1153 - 1157 (2006); received December 13, 2005 \\ A new bidesmosidic furostanol saponin was isolated from leaves of Furcraea gigantea Vent. \\ Its structure was established as 3-[(O-6-deoxy- $\alpha$-L-mannopyranosyl- $(1 \rightarrow 4)-O-\beta$-D-glucopyranos- \\ yl-( $1 \rightarrow 3)-O$ - $[O-\beta$-D-glucopyranosyl- $(1 \rightarrow 3)-\beta$-D-glucopyranosyl-( $1 \rightarrow 2)-O-\beta$-D-glucopyranosyl- \\ $(1 \rightarrow 4)$ - $\beta$-D-galactopyranosyl)oxy]-( $3 \beta, 5 \alpha, 15 \alpha, 22 \alpha, 25 R)$-26-( $\beta$-D-glucopyranosyloxy)-15,22-di- \\ hydroxy-furost-12-one. Its structural identification was performed using detailed analyses of ${ }^{1} \mathrm{H}$ \\ and ${ }^{13} \mathrm{C}$ NMR spectra including 2D NMR spectroscopic techniques (DEPT, COSY, HETCOR and \\ COLOC) and chemical conversions. The steroidal saponin showed no haemolytic effects in the in \\ vitro assays and demonstrated inhibition of the capillary permeability activity.
}

Key words: Furcraea gigantea, Agavaceae, Steroidal Saponin, anti-Inflammatory Activity

Furcraea gigantea Vent. (Agavaceae) is native to Brazil and is used in the folk medicine as an active diuretic and is claimed to be an effective remedy for venereal diseases, clarifying the urine. A slightly roasted leaf section is applied on any tumor or swelling. The juice of a roasted leaf is extracted and applied on ulcers, fistulas and wounds [1,2]. As part of our programme on the chemical investigation of bioactive steroidal saponins, we have now examined the leaves of $F$. gigantea. In this paper, we provide an account of the structural determination of a new bisdesmosidic furostanol saponin by its spectral data and chemical conversions. The haemolytic property and the anti-inflammatory activity of the isolated saponin were investigated.

\section{Experimental Section}

\section{Plant material}

Fresh leaves of Furcraea gigantea Vent. were obtained in September 2000 from plants cultivated at the Botanical Garden of Federal University of Rio de Janeiro, Brazil, and a voucher specimen is maintained in the Laboratory of Chemistry of Medicinal Plants at this University.

\section{General procedures}

Melting points were determined by an Electrothermal 9200 micro-melting point apparatus and are uncorrected. The optical rotations were measured on a Perkin Elmer 243B po- larimeter. IR spectra were measured on a Perkin Elmer 599B spectrometer. The MALDI-TOFMS was conducted using a Perseptive Voyager RP mass spectrometer. GC-MS analyses were performed with a Shimadzu GCMS-QP5050A gas chromatograph mass spectrometer using an ionization voltage of $70 \mathrm{eV}$ and an ionization current of $60 \mu \mathrm{A}$ for EI. GC was carried out with FID using a DB-1 glass capillary column $(0.25 \times 25 \mathrm{~m}, 0.25$ micron; J. \& W. Scientific Incorporated, Folsom, CA, USA). NMR spectra were measured in pyridine- $d_{5}\left(80 \mathrm{mg}\right.$ of $\mathbf{1}$ in $0.5 \mathrm{ml}$ ) at $25{ }^{\circ} \mathrm{C}$ with a Varian Gemini 200 NMR spectrometer, with tetramethylsilane $(\delta=0.00)$ used as internal standard. ${ }^{1} \mathrm{H}$ NMR spectra were recorded at $200 \mathrm{MHz}$ and ${ }^{13} \mathrm{C} \mathrm{NMR}$ spectra at $50 \mathrm{MHz}$. Silica gel columns (230-400 mesh ASTM, Merck) and Sephadex LH-20 (Pharmacia) were used for CC. TLC was performed on silica gel plates (Kieselgel $60 \mathrm{~F}_{254}$, Merck) using the following solvent systems: (A) $\mathrm{CHCl}_{3} / \mathrm{MeOH} / \mathrm{H}_{2} \mathrm{O}$ $(65: 35: 10 \mathrm{v} / \mathrm{v} / \mathrm{v}$, lower phase) for steroidal saponin 1, (B) $\mathrm{CHCl}_{3} / \mathrm{MeOH}(95: 5 \mathrm{v} / \mathrm{v})$ for pseudosapogenin and (C) $n-\mathrm{BuOH} / \mathrm{Me}_{2} \mathrm{CO} / \mathrm{MeOH}(4: 5: 1 \mathrm{v} / \mathrm{v} / \mathrm{v})$ for monosaccharides. Spray reagents were orcinol $/ \mathrm{H}_{2} \mathrm{SO}_{4}$ for steroidal saponin 1 and $\mathrm{CeSO}_{4}$ for pseudosapogenin.

\section{Extraction and isolation}

Fresh leaves of $F$. gigantea $(2.0 \mathrm{~kg})$ were extracted with $\mathrm{MeOH}(8.0 \mathrm{l})$ for $72 \mathrm{~h}$ at r.t. The extract was concentrated under reduced pressure to remove most of the $\mathrm{MeOH}$ and the resulting aqueous phase was shaken with $n-\mathrm{BuOH}$ [water $/ n-\mathrm{BuOH}(1: 1 \mathrm{v} / \mathrm{v})]$. This procedure was repeated and the resulting organic phase was evaporated in vacuum. The 
residue (7.3 g) was dissolved in $\mathrm{MeOH}(100 \mathrm{ml})$ and roughly chromatographed (365 $\mathrm{mg} / 5 \mathrm{ml}$ each time) on Sephadex LH-20 $(3.8 \times 65 \mathrm{~cm})$ with $\mathrm{MeOH}$. The fractions were combined based on the TLC profiles to give the saponin mixture $(730 \mathrm{mg}$ ). Further purification by chromatography on a silica gel column $(2.8 \times 90 \mathrm{~cm})$ eluted with $\mathrm{CHCl}_{3} / \mathrm{MeOH} / \mathrm{H}_{2} \mathrm{O}$ ( $7: 3: 1$, lower phase) provided a TLC homogeneous compound $1\left(173 \mathrm{mg}, R_{f} 0.30\right)$ which gave a dark blue colour with orcinol $/ \mathrm{H}_{2} \mathrm{SO}_{4}$.

\section{Compound 1}

Colorless needles. - M.p. $>280{ }^{\circ} \mathrm{C} .-[\alpha]_{\mathrm{D}}^{25}-54^{\circ}$ (c $0.1, \mathrm{MeOH}) . \quad-$ IR $(\mathrm{KBr}): v=3424(\mathrm{O}-\mathrm{H}), 2928$ (C-H), $1707(\mathrm{C}=\mathrm{O}), 1647,1452,1425,1378,1313,1260$, 1159, $1074(\mathrm{C}-\mathrm{O}), 1037(\mathrm{C}-\mathrm{O}), 913,896$ and $584 \mathrm{~cm}^{-1}$ [(25R-furostanol, intensity $\left.913<896 \mathrm{~cm}^{-1}\right] .-{ }^{1} \mathrm{H}$ NMR (200 MHz, pyridine- $d_{5}$ ): $\delta=0.70(\mathrm{~s}, 3 \mathrm{H}, 19-\mathrm{Me}), 0.99$ (d, $J=6.6 \mathrm{~Hz}, 3 \mathrm{H}, 27-\mathrm{Me}), 1.18$ (s, 3H, 18-Me), 1.37 $(\mathrm{d}, J=6.9 \mathrm{~Hz}, 3 \mathrm{H}, 21-\mathrm{Me}), 1.71(\mathrm{~d}, J=6.2 \mathrm{~Hz}, 3 \mathrm{H}$, Rha-6-Me), 3.85 (br m, 1H, 3-H), 4.54 (dd, $J=11.0,4.0 \mathrm{~Hz}$, $1 \mathrm{H}, 15-\mathrm{H}), 4.58(\mathrm{dd}, J=9.0,4.0 \mathrm{~Hz}, 1 \mathrm{H}, 16-\mathrm{H}), 4.84(\mathrm{~d}$, $J=7.8 \mathrm{~Hz}, 2 \mathrm{H}$, Gal-1-H and Glc-1'"'-H), 5.05 (d, $J=7.5 \mathrm{~Hz}$, $1 \mathrm{H}$, Glc-1"-H), 5.08 (d, $J=7.8 \mathrm{~Hz}, 1 \mathrm{H}$, Glc-1-H), 5.14 (d, $J=8.0 \mathrm{~Hz}, 1 \mathrm{H}$, Glc-1"'-H), $5.50(\mathrm{~d}, J=7.5 \mathrm{~Hz}, 1 \mathrm{H}$, Glc-1'-H), 5.75 (br s, 1H, Rha-1-H). $-{ }^{13} \mathrm{C}$ NMR (50 MHz, pyridine- $\left.d_{5}\right): \delta=11.83(\mathrm{C}-19, \mathrm{CMe}), 13.93(\mathrm{C}-21, \mathrm{CHMe})$, 16.78 (C-27, CHMe), 17.35 (C-18, CMe), 18.0 (Rha-C-6, $\mathrm{CHMe}), 27.75\left(\mathrm{C}-24, \mathrm{CH}_{2}\right), 28.84\left(\mathrm{C}-6, \mathrm{CH}_{2}\right), 29.73(\mathrm{C}-2$, $\left.\mathrm{CH}_{2}\right), 30.23\left(\mathrm{C}-23, \mathrm{CH}_{2}\right), 32.05\left(\mathrm{C}-7, \mathrm{CH}_{2}\right), 33.76(\mathrm{C}-25$, $\mathrm{CH}), 34.65\left(\mathrm{C}-4, \mathrm{CH}_{2}\right), 35.21(\mathrm{C}-8, \mathrm{CH}), 36.43(\mathrm{C}-10$, C), $36.63\left(\mathrm{C}-1, \mathrm{CH}_{2}\right), 37.74\left(\mathrm{C}-11, \mathrm{CH}_{2}\right), 42.69(\mathrm{C}-20$, $\mathrm{CH}), 44.38(\mathrm{C}-5, \mathrm{CH}), 51.83(\mathrm{C}-17, \mathrm{CH}), 54.79(\mathrm{C}-13, \mathrm{C})$, 55.41 (C-9, CH), 60.28 (C-14, CH; Gal-C-6, $\mathrm{CH}_{2}$ ), 60.74 (Glc-C-6"', $\mathrm{CH}_{2}$ ), 61.65 (Glc-C-6', $\mathrm{CH}_{2}$ ), 62.03 (Glc-C-6", $\mathrm{CH}_{2}$ ), 62.43 (Glc-C-6, $\mathrm{CH}_{2}$ ), 63.01 (Glc-C-6'"', $\mathrm{CH}_{2}$ ), 68.94 (Glc-C-4', CH), 69.90 (Rha-C-5, CH), 70.13 (Glc-C-4, CH), 71.09 (Glc-C-4", CH), 71.69 (Glc-C-4"”, CH), 71.95 (Rha-C-2, CH), 72.14 (Rha-C-3, CH), 73.38 (Rha-C-4, CH), 74.23 (Glc-C-2', CH), $74.74\left(\mathrm{C}-26, \mathrm{CH}_{2}\right), 74.82$ (C-5, CH), 75.04 (C-3, CH; Glc-C-2", CH; Glc-C-2"', CH), 75.22 (Glc-C-2'"', CH), 76.01 (Glc-C-3"', CH), 76.60 (Gal-C-2, $\mathrm{CH}$ ), 76.67 (Glc-C-5"', CH), 76.88 (Glc-C-5, CH), 77.13 (C-3, CH), 77.47 (Glc-C-5', CH; Glc-C-3", CH; Glc-C-4"', $\mathrm{CH}), 77.83$ (C-15, CH), 77.89 (Glc-C-5”, CH, 78.51 (Glc-C-5"', CH), 78.61 (Glc-C-3"'”, CH), 79.60 (Gal-C-4, $\mathrm{CH}), 80.31$ (Glc-C-2, CH), 87.45 (Glc-C-3, CH; Glc-C-3', $\mathrm{CH}), 89.93$ (C-16, CH), 102.09 (Gal-C-1, CH), 103.42 (Rha-C-1, CH), 103.59 (Glc-C-1', CH), 104.12 (Glc-C-1"', CH), 104.40 (Glc-C-1, CH), 104.92 (Glc-C-1", CH), 105.01 (Glc-C-1"', CH), 110.58 (C-22, C), 212.68 (C-12, C=O). MALDI-TOFMS: $m / z=1606.6391[\mathrm{M}+\mathrm{Na}]^{+}$(calcd. for $\mathrm{C}_{69} \mathrm{H}_{114} \mathrm{O}_{40} \mathrm{Na}:$ 1606.6403).

\section{Acid hydrolysis of $\mathbf{1}$}

A solution of saponin $1(100 \mathrm{mg})$ in $1 \mathrm{M} \mathrm{HCl} / 1$,4-dioxan $(1: 1 \mathrm{v} / \mathrm{v} ; 10 \mathrm{ml})$ was heated in a sealed tube for $1 \mathrm{~h}$ at $100{ }^{\circ} \mathrm{C}$. After cooling, the reaction mixture was neutralyzed with $3 \% \mathrm{KOH}$ in $\mathrm{MeOH}$ and evaporated to dryness. The salts that deposited on addition of $\mathrm{MeOH}$ were filtered off and the filtrate was passed through a Sephadex $\mathrm{LH}-20$ with $\mathrm{MeOH}$ to give the hydrolysate $(91 \mathrm{mg})$ which was chromatographed on silica gel CC with $\mathrm{CHCl}_{3} / \mathrm{MeOH} / \mathrm{H}_{2} \mathrm{O}(7: 3: 0.1 \mathrm{v} / \mathrm{v} / \mathrm{v})$ to yield the pseudosapogenin $(12.7 \mathrm{mg})$ and a sugar mixture. Identity of aglycone was established by comparison with spectral data through IR, ${ }^{1} \mathrm{H}$ and ${ }^{13} \mathrm{C}$ NMR and EIMS [3]. The sugar mixture was dissolved in pyridine and analyzed by silica gel-TLC in the above described solvent system (C). After spraying with orcinol $/ \mathrm{H}_{2} \mathrm{SO}_{4}$, rhamnose gave a green spot at $R_{f} 0.75$, glucose gave a blue spot at $R_{f} 0.70$ and galactose gave a purple spot at $R_{f} 0.66$.

\section{Molar carbohydrate composition and D,L configurations}

The molar carbohydrate composition of compound $\mathbf{1}$ was determined by GC-MS analysis of its monosaccharides as their trimethylsilylated methylglycosides obtained after methanolysis $\left(0.5 \mathrm{M} \mathrm{HCl}\right.$ in $\left.\mathrm{MeOH}, 24 \mathrm{~h}, 80^{\circ} \mathrm{C}\right)$ and trimethylsilylation [4]. The configurations of the glycosides were established by capillary GC of their trimethylsilylated (-)-2-butylglycosides [5].

\section{Methylation analysis}

Compound $\mathbf{1}$ was methylated with dimethyl sulfoxide/lithium methylsulfinyl carbanion/methyl iodide [6]. The methyl ethers were obtained after hydrolysis ( $4 \mathrm{~N}$ trifluoroacetic acid, $2 \mathrm{~h}, 100{ }^{\circ} \mathrm{C}$ ) and analyzed as partially alditol acetates by GC-MS [7].

\section{Animals}

Male BALB/c mice, weighing 15-20 g, were used. The animals were housed under standard environmental conditions and fed with standard rodent diet and water ad libitum.

\section{Statistical analysis}

The experimental data were tested for statistical differences using the Student's $t$ test. $\mathrm{IC}_{50}$ values were obtained from the regression lines.

\section{Haemolytic activity}

Normal human red blood cell suspension $(0.6 \mathrm{ml}$ of $0.5 \%)$ was mixed with $0.6 \mathrm{ml}$ diluent containing 5, 10, 20, 30, 40, $50,100,250$ and $500 \mu \mathrm{g} / \mathrm{ml}$ of compound 1, aluminum hydroxide, and 5-500 $\mu \mathrm{l} / \mathrm{ml}$ of Freund's Complete Adjuvant 
(FCA) and Freund's Incomplete Adjuvant (FIA) in saline solution. Mixtures were incubated for $30 \mathrm{~min}$ at $37^{\circ} \mathrm{C}$ and centrifuged at $70 \times g$ for $10 \mathrm{~min}$. Saline and distilled water were included as minimal and maximal haemolytic controls. The haemolytic percents developed by the saline control were subtracted from all groups. The adjuvant concentration inducing $50 \%$ of the maximum haemolysis was considered the $\mathrm{HD}_{50}$ (graphical interpolation). Experiments included triplicate at each concentration [8].

\section{anti-Inflammatory activity}

anti-Inflammatory activity was evaluated by measuring acetic acid-induced vascular permeability [9]. Male mice (BALB/c, 15-20 g) in groups of five were dosed orally with different concentrations of compound $1(10,25,50$ and $100 \mathrm{mg} / \mathrm{kg}$ body weight) and a positive control, indomethacin $(10 \mathrm{mg} / \mathrm{kg}$ body weight). After injection of the dye, $0.1 \mathrm{~N}$ acetic acid $(10 \mathrm{ml} / \mathrm{kg}$ body weight $)$ was injected intraperitoneally. $20 \mathrm{~min}$ later, the mice were killed with an overdose of ether and the viscera were exposed after a 1 min period to allow blood to drain away from the abdominal wall. The animal was held by a flap of the abdominal wall and the viscera were irrigated with $10 \mathrm{ml}$ of saline over a petri dish. The washing was filtered through glass wool and transferred to a test tube. To each tube was added $100 \mu \mathrm{l}$ of $1 \mathrm{~N} \mathrm{NaOH}$ in order to clear any turbidity due to protein, and the absorbance was read at $590 \mathrm{~nm}$.

\section{Result and Discussion}

Compound 1 was obtained as colorless needles and gave a positive Liebermann-Burchard test for a steroidal saponin. It revealed a quasi-molecular ion peak at $m / z=1606.6391[\mathrm{M}+\mathrm{Na}]^{+}$in the MALDITOFMS. In the ${ }^{13} \mathrm{C}$ NMR spectrum, 69 carbon signals observed belong to five methyl groups, fifteen methylene groups (seven of which were oxygenated), forty five methine groups (thirty eight of which were oxygenated) and four quaternary carbon atoms (two of which were oxygenated). On the basis of above mentioned MS and NMR spectral data, compound 1 was supposed to be a saponin with the molecular formula $\mathrm{C}_{69} \mathrm{H}_{114} \mathrm{O}_{40}$, bearing a chain of seven sugar moieties.

In addition to this, the furostanol glycosidic nature of compound $\mathbf{1}$ was indicated by the strong absorption bands at 3424 and $1074 \mathrm{~cm}^{-1}$ and a $25 R$-furostan steroidal structure $\left(896\right.$ and $913 \mathrm{~cm}^{-1}$, intensity $913<$ $896 \mathrm{~cm}^{-1}$ ) in the IR spectrum [10], confirmed by ${ }^{1} \mathrm{H}$ and ${ }^{13} \mathrm{C}$ NMR spectra $[3,11]$. The ${ }^{1} \mathrm{H}$ NMR spectral data contained signals for three hydrogens at $\delta=3.85$ (br m, H-3), 4.54 (dd, $J=11.0$ and $J=4.0 \mathrm{~Hz}, \mathrm{H}-15$ ) and $4.58(\mathrm{dd}, J=9.0$ and $J=4.0 \mathrm{~Hz}, \mathrm{H}-16)$, two secondary methyl hydrogens at $\delta=1.37(\mathrm{~d}, J=6.9 \mathrm{~Hz}$, $3 \mathrm{H}-21)$ and 0.99 (d, $J=6.6 \mathrm{~Hz}, 3 \mathrm{H}-27)$ and two angular methyl hydrogens at $\delta=1.18(\mathrm{~s}, 3 \mathrm{H}-18)$ and 0.70 (s, 3H-19). The above ${ }^{1} \mathrm{H}$ NMR spectral data and a comparison of the ${ }^{13} \mathrm{C}$ NMR signals of the above ${ }^{1} \mathrm{H}$ NMR spectral data and a comparison of the ${ }^{13} \mathrm{C}$ NMR signals of the aglycone moiety of $\mathbf{1}$ with those described in the literature [3] suggest the structure of the aglycone to be 3,15,22,26-tetrahydroxy-( $3 \beta, 5 \alpha, 15 \alpha, 22 \alpha, 25 R)$-furostan-12-one. In addition to this, the ${ }^{1} \mathrm{H}$ NMR spectrum of 1 showed seven anomeric hydrogens at $\delta=4.84(\mathrm{~d}, J=7.8 \mathrm{~Hz}$, $2 \mathrm{H}), 5.05(\mathrm{~d}, J=7.5 \mathrm{~Hz}, 1 \mathrm{H}), 5.08(\mathrm{~d}, J=7.8 \mathrm{~Hz}$, $1 \mathrm{H}), 5.14(\mathrm{~d}, J=8.0 \mathrm{~Hz}, 1 \mathrm{H}), 5.50(\mathrm{~d}, J=7.5 \mathrm{~Hz}$, $1 \mathrm{H})$ and $5.75(\mathrm{~s}, 1 \mathrm{H})$ corresponding to $\mathrm{Gal}-\mathrm{H}-1$ and Glc-H-1"', Glc-H-1", Glc-H-1, Glc-H-1"', Glc-H-1' and Rha-H-1, respectively, indicating $\beta$-anomeric configuration for galactose and five glucoses and $\alpha$-anomeric configuration for rhamnose. The ${ }^{13} \mathrm{C}$ NMR spectroscopic data for the sugar moieties indicated that all the monosaccharides were in pyranose form.

In the ${ }^{13} \mathrm{C}$ NMR spectrum of compound $\mathbf{1}$, a 1,4-linked inner $\beta$-D-galactopyranosyl unit, a 1,2,3-linked inner $\beta$-D-glucopyranosyl unit, a 1,3-linked inner $\beta$-D-glucopyranosyl unit, a 1,4-linked inner $\beta$-D-glucopyranosyl unit, two terminal $\beta$-Dglucopyranosyl units and a terminal $\alpha$-L-rhamnopyranosyl unit were observed. The ${ }^{1} \mathrm{H}$ and ${ }^{13} \mathrm{C}$ NMR chemical shift assignments were made by standard 1D and 2D NMR techniques $\left({ }^{1} \mathrm{H}-{ }^{1} \mathrm{H}-\mathrm{COSY}\right.$, DEPT, HETCOR and COLOC experiments). Its COLOC spectrum displayed long range couplings between galactose-H-1 at $\delta=4.84$ and aglycone-C-3 at $\delta=77.13$, between glucose-H-1"'" at $\delta=4.84$ and aglycone-C-26 at $\delta=74.74$, between glucose-H-1" at $\delta=5.05$ and glucose-C-3' at $\delta=87.45$, between glucose-H-1 at $\delta=5.08$ and galactose-C- 4 at $\delta=79.60$, between glucose-H-1" "at $\delta=5.14$ and glucose-C-3 at $\delta=87.45$, between glucose-H-1' at $\delta=5.50$ and Glc-C-2 at $\delta=80.31$ and between rhamnose-H-1 at $\delta=5.75$ and glucose-C-4"' at $\delta=77.47$. In addition to this, the methylation analysis of compound 1 furnished 1,5-di- $O$-acetyl-2,3,4,-tri$O$-methyl rhamnitol, 1,5-di- $O$-acetyl-2,3,4,6-tetra- $O$ methyl glucitol, 1,3,5-tri- $O$-acetyl-2,4,6-tri- $O$-methyl glucitol, 1,4,5-tri- $O$-acetyl-2,3,6-tri- $O$-methyl glucitol, $1,4,5$-tri- $O$-acetyl-2,3,6-tri- $O$-methyl galactitol and 1,2,3,5-tetra- $O$-acetyl-4,6-di- $O$-methyl glucitol. These 


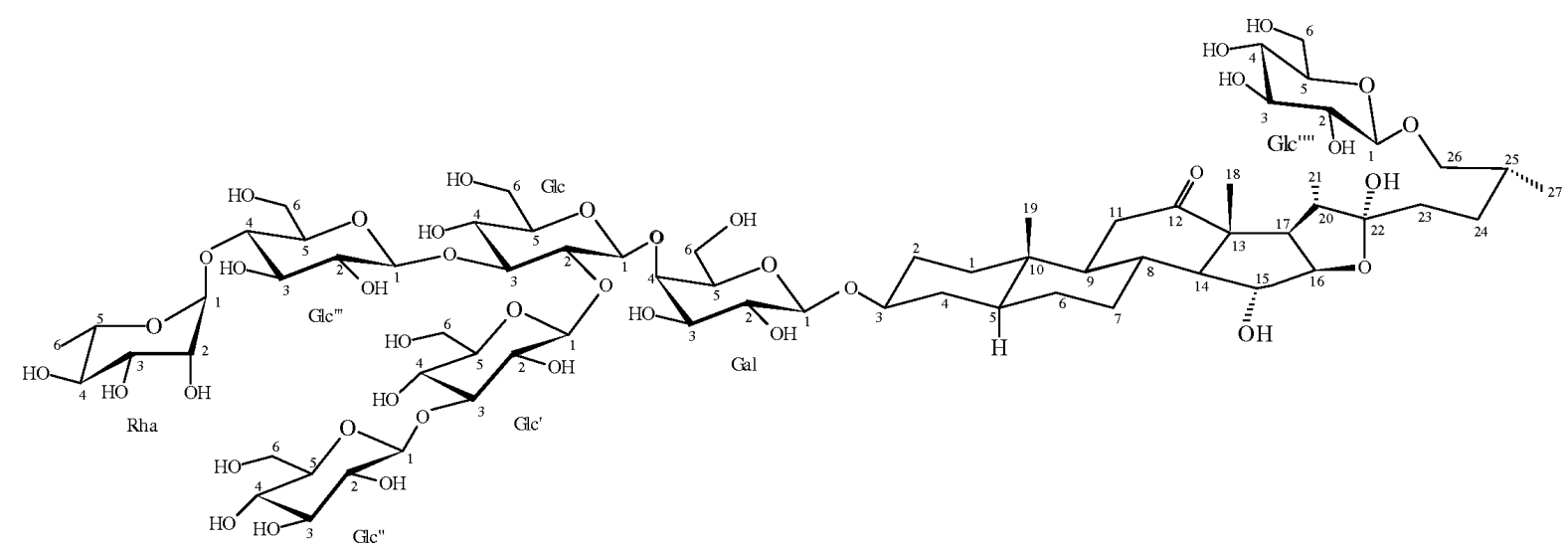

Fig. 1. 3-[( $O$-6-deoxy- $\alpha$-L-mannopyranosyl-( $1 \rightarrow 4)-O-\beta$-D-glucopyranosyl- $(1 \rightarrow 3)-O$ - $[O-\beta$-D-glucopyranosyl- $(1 \rightarrow 3)-\beta$-Dglucopyranosyl- $(1 \rightarrow 2)-O$ - $\beta$-D-glucopyranosyl- $(1 \rightarrow 4)-\beta$-D-galactopyranosyl)oxy]-(3 $\beta, 5 \alpha, 15 \alpha, 22 \alpha, 25 R)-26$ - $(\beta$-D-glucopyranosyloxy)-15,22-dihydroxy-furost-12-one (1).

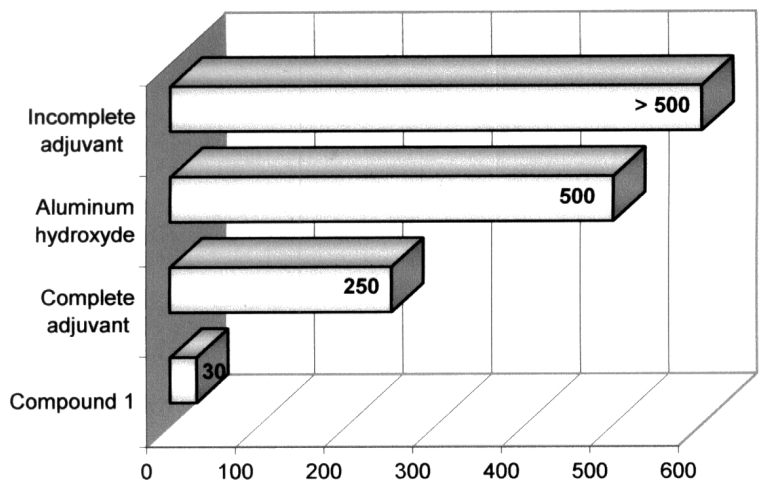

Fig. 2. 50\% Haemolytic dose $(\mu \mathrm{g} / \mathrm{ml})$ of compound 1 and adjuvants.

results indicated that compound $\mathbf{1}$ is undoubtedly as shown in Fig. 1.

On acid hydrolysis, compound $\mathbf{1}$ gave a pseudosapogenin, galactose, glucose and rhamnose. The pseudosapogenin was identified as 3,15-dihydroxy-(3 $\beta, 5 \alpha, 15 \alpha, 25 R)$-spirostan-12-one. Its identity was established by comparison with spectral data through IR, ${ }^{1} \mathrm{H}$ and ${ }^{13} \mathrm{C}$ NMR and EIMS [3]. The molar carbohydrate composition of compound $\mathbf{1}$ indicated the presence of seven neutral monosaccharides: galactose-glucose-rhamnose $(1: 5: 1)$ [4]. Their absolute configurations were determined by GC of their trimethylsilylated (-)-2-butylglycosides [5]. D-galactose, D-glucose and L-rhamnose were identified. Consequently, on the basis of IR, ${ }^{1} \mathrm{H}$ and ${ }^{13} \mathrm{C}$ NMR spectroscopy, MALDI-TOFMS and chemical reactions, the structure of compound $\mathbf{1}$ was

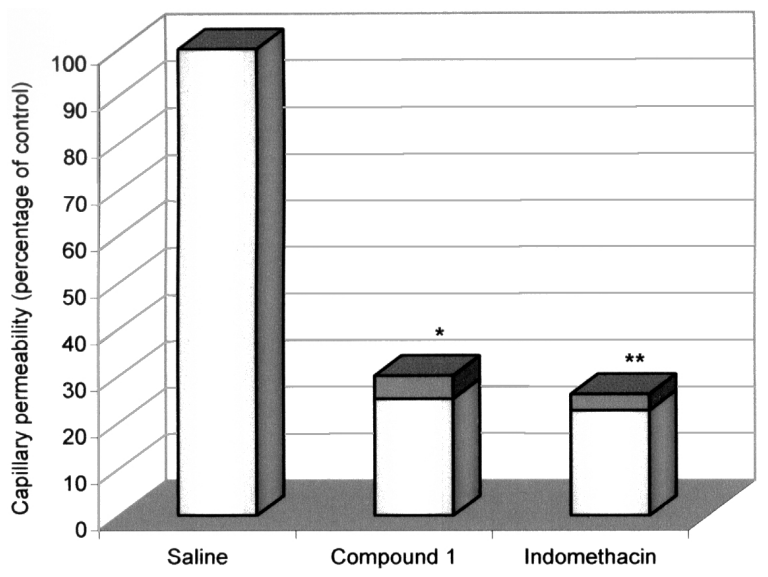

Fig. 3. Effect of compound 1 (100 mg/kg p.o.) on acetic acid-induced vascular permeability in mice. Standard, indomethacin $(10 \mathrm{mg} / \mathrm{kg}$ p.o.). Results are mean \pm S.E.M. $(n=5)$; $p<0.05, * * p<0.01$. vs. control. Student's $t$-test.

established as 3-[(O-6-deoxy- $\alpha$-L-mannopyranosyl$(1 \rightarrow 4)-O-\beta$-D-glucopyranosyl- $(1 \rightarrow 3)-O-[O-\beta$-Dglucopyranosyl-( $1 \longrightarrow 3)-\beta$-D-glucopyranosyl- $(1 \rightarrow 2)$ $O$ - $\beta$-D-glucopyranosyl-( $1 \rightarrow 4)$ - $\beta$-D-galactopyranosyl)oxy]-(3 $\beta, 5 \alpha, 15 \alpha, 22 \alpha, 25 R)$-26-( $\beta$-D-glucopyranosyloxy)-15,22-dihydroxy-furost-12-one.

On the basis of recent reports of haemolytic [12] and anti-inflammatory [13] activities of steroidal saponins, these pharmacological properties of compound 1 were investigated. The absence of haemolytic effect demonstrates that the membranolytic activity is related to the amphipathic nature of the molecule (Fig. 2). In addition to this, the capillary permeability assay (Whittle, 1964) was used to evaluate the anti-inflammatory ac- 
tivity of compound 1 (Fig. 3), which showed inhibition of the increase in vascular permeability caused by acetic acid, which is a typical model of first stage inflammatory reaction. The results obtained may help explain some biological properties attributed to steroidal saponins reported in the literature [14].

\section{Acknowledgements}

This work was financially supported by FUJB, CAPES, FINEP, and CNPq.
[1] R. Braga, Plantas do Nordeste, Especialmente do Ceará, p. 217, Escola Superior de Agricultura de Mossoró, Fortaleza (1976).

[2] G. Pompa, Medicamentos indígenas, p. 313, Editorial America S. A., Miami (1974).

[3] M. Kuroda, Y. Mimaki, F. Hasegawa, A. Yokosuka, Y. Sashida, H. Sakagami, Chem. Pharm. Bull. 49, 726 (2001).

[4] J. P. Kamerling, G. J. Gerwig, J. F. G. Vliegenthart, J. R. Clamp, Biochem. J. 151, 491 (1975).

[5] G. J. Gerwig, J. P. Kamerling, J. F. G. Vliegenthart, Carbohydr. Res. 62, 349 (1978).

[6] J. P. Parente, P. Cardon, Y. Leroy, J. Montreuil, B. Fournet, G. Ricart, Carbohydr. Res. 141, 41 (1985).

[7] J. S. Sawardeker, J. H. Sloneker, A. Jeanes, Anal. Chem. 37, 1602 (1965).
[8] W.R. Santos, R.R. Bernardo, L.M.T. Peçanha, M. Palatnik, J. P. Parente, C. B. P. de Sousa, Vaccine 15, 1024 (1997).

[9] B. A. Whittle, Br. J. Pharmacol. Chemother. 22, 246 (1964).

[10] M.E. Wall, C.R. Eddy, M.L. McClennan, M.E. Klump, Anal. Chem. 24, 1337 (1952).

[11] P. K. Agrawal, D. C. Jain, R. K. Gupta, R. S. Thakur, Phytochemistry 24, 2479 (1985).

[12] K. Oda, H. Matsuda, T. Murakami, S. Katayama, T. Ohgitani, M. Yoshikawa, Biol. Chem. 381, 67 (2000).

[13] S. M. Abdel-Khalik, T. Miyase, F. R. Melek, O. A. ElShabraway, I. I. Mahmoud, S. A. Mina, Pharmazie 57, 562 (2002).

[14] M. A. Lacaille-Dubois, H. Wagner, Phytomedicine 2, 363 (1996). 